\title{
Investigating the Relationship between Over-Valuation Stock Price and Debt Costs of Companies with Financial Health Based on Black, Scholes and Merton (BSM) Model
}

\author{
Gholam Reza-Zomorodian and Majid Rahmani Firozjaee* \\ Islamic Azad University Central Tehran Branch, Tehran, Iran
}

\begin{abstract}
This study aims to investigate the relationship between over-valuation stock price and debt costs of companies with financial health in Tehran Stock Exchange. In this regard, at first the researcher identifies companies with financial health based on Black, Scholes and Merton (BSM) model, and then tests the hypotheses. This study is applied and according to the data collection method, it is descriptive (correlation) with ratio scale of measuring data. To test the hypotheses, we collect the accounting data from 2011 to 2015 and analyze the data based on it. According to the results, there is a positive and significant relationship between the over-valuation and the debt cost of companies with financial health, and the relationship is intensified by the information asymmetry. The results of this study confirm the findings of Chiou and Shu research on the existence of a positive and significant relationship between over-valuation and debt costs.
\end{abstract}

Keywords: Over-valuation; Debt costs; Stock; Black; Scholes and Merton Model (BSM)

\section{Introduction}

The over-valuation means higher stock price than its intrinsic value. These conditions not only encourage investors to overestimate the prices of products and services, but also cause managers to become involved in inappropriate practices. The over-valuation is often observed in inefficient markets and is often supported [1]. Rostami et al. [2] point out that, managers also have the required motivation to maximize stock prices and make them permanent. Modigliani and Miller [3] stated that the more over-valuation would be increased; managers are less interested to use the earnings management within the accepted accounting principles framework. The findings of Houmes and Skantz [4] indicate that there is a reverse relationship between audit quality and discretionary accruals in over-valued companies. According to Polk and Sapienza [5], over-valuation has two effects: first, it produces high profits for current shareholders, and secondly, it increases the optimistic expectations of the company in order to invest in opportunities ahead. On the other hand, the results of Hua [6] stated that there is a significant relationship between financial leverage and information asymmetry. They also suggested that the cost of corporate capital also increases with increasing information asymmetry. Companies need to attract funds to finance their projects, which can finance by loans or bonds. That is, the debt cost is actually the cost that a company will incur for the funds provided by the loan or the long-term bonds. This rate reflects the expected returns of lenders. Therefore, financial providers are paying much attention to the ability of company to pay for debt. One of the factors that have a direct effect on the cost of debt is the default risk. In turn, default risk is associated with uncertainty about the ability of company to meet obligations and debt repayment. This risk is usually estimated by different criteria that the most common criteria include: Altman Z-score, Olson score, credit ranks, debt repayment differentials, and market criteria based on the BSM model [7]. In this study, for accurate estimation of the effect of over-valuation on debt cost and also innovation creation towards other research, we will examine the effect of over-valuation on debt cost. So, according to the above subject matter, we intend to answer the question about how much the over-valuation effects on the debt cost of companies with financial health in the Tehran Stock Exchange.

\section{Theoretical Foundations, Research Background}

The findings of Chiou and Shu [1] show that over-valuation of companies has a direct and positive relationship with the cost of financing. Also, these findings show that the high cost rate of the bank loan would reduce the over-valuation of companies and representative costs. Evidence from Loughran and Ritter's research [8] study, companies that are unrealistically valued are more exposed to the risk of falling stock prices. The results by Mc Laughlin et al. [9] confirm that information asymmetry and the fraud possibility are minimized by increasing information transparency, capital cost decreases and company value increases. Bhattacharya et al. [10] stated that low earning quality leads to increase the information asymmetry in financial markets. The findings of Wassan and Boone [11] reported that there is no significant positive relationship between discretionary accruals and information asymmetry. The results of Spiess and Graves [12] suggested that the overall quality of company's disclosure transparency has a positive relationship with financial performance of companies. The findings of Habib and Hasan [13] show that over-valued companies are at a higher risk than other companies. The findings of Izadinia and Mirzaei [14] show that there is a positive and significant relationship between the interactive effect of over-valuation of stock and the criteria audit quality. According to findings, Rezaei [15] states that there is a positive correlation between the over-valued stock and profit smoothing variables. The results of Vadiee and Azimifar [16] show that high valued companies will report more current discretionary accruals compared to the low-valued companies at current year. According to Babrbaian [17], managers manipulate earnings to conceal over-

*Corresponding author: Majid Rahmani Firozjaee, PhD Student, Financial Engineering, Islamic Azad University Central Tehran Branch, Tehran, Iran, Tel: +9866940203; E-mail:mrfmajid@yahoo.com

Received April 11, 2018; Accepted May 08, 2018; Published May 21, 2018

Citation: Reza-Zomorodian G, Firozjaee MR (2018) Investigating the Relationship between Over-Valuation Stock Price and Debt Costs of Companies with Financia Health Based on Black, Scholes and Merton (BSM) Model. J Account Mark 7: 275. doi: 10.4172/2168-9601.1000275

Copyright: (c) 2018 Reza-Zomorodian G, et al. This is an open-access article distributed under the terms of the Creative Commons Attribution License, which permits unrestricted use, distribution, and reproduction in any medium, provided the original author and source are credited. 
Citation: Reza-Zomorodian G, Firozjaee MR (2018) Investigating the Relationship between Over-Valuation Stock Price and Debt Costs of Companies with Financial Health Based on Black, Scholes and Merton (BSM) Model. J Account Mark 7: 275. doi: 10.4172/2168-9601.1000275

Page 2 of 5

valuation of company. Mousavi et al. [18] stated that there is a positive and significant relationship between stock valuation and increasing earnings management in subsequent periods.

According to that investigating the relationship between overvaluation and the debt cost of bank is an essential factor for investing and making investors and creditors better familiar with the capital market, it is necessary to study in this field; and we try to answer the question whether there is a significant effect of over-valuation of stock and information asymmetry on the debt cost of bank of the listed companies in the Tehran Stock Exchange; and if this is the case, how can this effect be interpreted? In this regard, the following hypotheses are defined:

1. The over-valuation has a positive and significant relationship with the debt cost.

2. The information asymmetry will intensify the relationship between over-valuation and debt cost.

\section{Research Method}

This study is applied and according to the data collection method, it is descriptive (correlation) with ratio scale of measuring data. To test the hypotheses, we collected the accounting data from 2011 to 2015, which have the following characteristics:

1. The fiscal year of the companies will end in March.

2. There is a company's balance sheet information. Meanwhile, companies' stocks have no negative book value or zero.

3. There is no stop trading for more than five months (they have return at least in nine months of the year).

4. The companies' market value is available at the end of each year.

So, we use the all active companies in the stock exchange between 2011 and 2015 which are eligible.

Meanwhile, the researcher is used the companies with financial health to investigate the effect of over-valuation factor on debt costs. To identify and extract the companies with financial health, we use proposed BSM model by Li and Xia [19] as follows:

$$
\begin{aligned}
& P_{d e f, i t}=N\left(\frac{\ln \frac{E_{i t}+F_{i t}}{F_{i t}}+\left(r_{i, t-1}-\frac{\dot{\mathrm{o}}_{V_{i t}}^{2}}{2}\right)(T)}{\dot{\mathrm{o}}_{V i t} \sqrt{T}}\right) \\
& \sigma_{V_{i t}}=\frac{E_{i t}}{E_{i t}+F_{i t}} \sigma_{E_{i t}}+\frac{F_{i t}}{E_{i t}+F_{i t}}\left(0.05+0.25 \sigma_{E_{i t}}\right)
\end{aligned}
$$

$E_{i t}$ is the stock market value of company at the end of year $t, F_{i t}$ is the nominal value of the company's debts at the end of year $t$ (equal to the total short-term debt and $50 \%$ of long-term debt), $r_{i t-1}$ is the annual return of company $\mathrm{i}$ in year $\mathrm{t}-1, \sigma_{\mathrm{vit}}$ is approximate volatility of the company value at the end of year $t, \sigma_{\mathrm{Eit}}$ is the volatility of stock returns $\mathrm{i}$ in year $\mathrm{t}$ (is calculated using the standard deviation of the monthly stock returns of the company in year $\mathrm{t}-1$ ). $\mathrm{T}$ is deadline (one year is considered). $\mathrm{N}(0)$ is cumulative probability of normal distribution.

BSM is a company-specific criterion that calculates the value of each company based on the financial situation and financial resources and capital resources, not based on its credit rating, as a result it provides a more accurate rating [7]. Based on the results, the results of companies' model can be divided into three categories (Table 1).

\begin{tabular}{|c|c|}
\hline The result of computing BSM & Company status \\
\hline $\mathrm{BSM}<0.33$ & Companies with financial health \\
\hline $0.33<\mathrm{BSM}<0.66$ & companies with moderate inability \\
\hline $\mathrm{BSM}>0.66$ & Companies with high inability \\
\hline
\end{tabular}

Table 1: Dividing companies based on the results of BSM.

As explained in the previous steps, in this study we use the companies with financial health. As a result, considering the above descriptions, 43 companies are selected for analysis.

\section{Research model}

According to the data of the study, which are a combination of time series and cross-sectional data, in other words, the combined data or panel, we use the data panel regression model. In this study, the following statistical model is used to examine the hypotheses:

$$
S L_{i t}=\beta_{0}+\beta_{1} O V_{i t}+\beta_{2} \text { Size }_{i t}+\beta_{3} R O A_{i t}+\beta_{4} R O E_{i t}+\beta_{5} L E V_{i t}+€_{i t}
$$

Where $\mathrm{SL}_{\mathrm{it}}$ is the cost of financing (bank debt) through a bank loan for company $\mathrm{i}$ in year $\mathrm{t}, \mathrm{OV}_{\mathrm{it}}$ is over-valuation of stock valuation for company $\mathrm{i}$ in year t, $\mathrm{ROA}_{\mathrm{it}}$ is Return on Assets for company $\mathrm{i}$ in year $t, \mathrm{ROE}_{\mathrm{it}}$ is Return on Equity for company $\mathrm{i}$ in year $\mathrm{t}, \mathrm{Size}_{\mathrm{it}}$ is size for company $i$ in year $t, L V_{i t}$ is the financial leverage for company $i$ in year $\mathrm{t}, \varepsilon_{\mathrm{it}}$ is model waste.

$$
\begin{aligned}
& S L_{i t}=\beta_{0}+\beta_{1} O V_{i t}+\beta_{2} H L_{-} 1 N i t_{i t}+\beta_{3} \operatorname{Size}_{i t}+\beta_{4} R O A_{i t}+\beta_{5} R O E_{i t}+\beta_{6} L E V_{i t}+\epsilon_{i t} \\
& \text { HL_INit: Information asymmetry }
\end{aligned}
$$

\section{Introducing the variables of research}

In this study, we use the over-valuation calculation of RhodesKroopf et al., [20] model. In this model, the market value to book value $\left(\frac{M}{B}\right)$ is used as a representative for inappropriate stock valuations and growth opportunities. They reported that if there is a correct criterion for the company's real value, the ratio of market value to book value can be divided into two parts:

$$
\frac{\mathrm{M}}{\mathrm{B}}=\frac{\mathrm{M}}{\mathrm{V}}, \frac{\mathrm{V}}{\mathrm{B}}
$$

In above equation, the market value to real value represents an incorrect valuation, and real value to book value represents growth opportunities. The logarithmic form of the above pattern can be explained as follows:

$$
\mathrm{m}-\mathrm{b}=(\mathrm{m}-\mathrm{v})+(\mathrm{v}-\mathrm{b})
$$

Rhodes-Kroopf et al. [20] argued that the real value is a linear function of the company'specific accounting information at a point in time (qit) and a vector of accounting and financial multiples ( $\alpha$ ) [1]

In this study, we use the bank debt ratio (paid interest and commission and total received credits) to calculate the debt cost of bank.

The natural logarithm of assets has been used to calculate the size of the company.

Size $=\ln ($ Size $)$

Size $_{\text {it }}$ is company size, $\ln$ (size) is natural logarithms of the company's assets $i$ in year t.

The rate of Return on Assets in this research is calculated as follows: 
Citation: Reza-Zomorodian G, Firozjaee MR (2018) Investigating the Relationship between Over-Valuation Stock Price and Debt Costs of Companies with Financial Health Based on Black, Scholes and Merton (BSM) Model. J Account Mark 7: 275. doi: 10.4172/2168-9601.1000275

Page 3 of 5

$$
\text { ROA }=\frac{\text { Net Profit }}{\text { Total Assets }}
$$

ROA $_{i t}$ is Return on Assets, Net Profit is net income of company i in year $t$, Total Assets is total assets of company $i$ in year $t$.

Information Asymmetry (HL_INit): In this study, we use the ownership percentage of non-institutional shareholders has been used to compute information asymmetry [21].

\section{Analyzing the Research Results}

\section{Descriptive statistics of research variables}

It is necessary to familiar with the descriptive statistics related to the variables in order to investigate the general and basic specifications of the variables in order to estimate the model, to analyze them accurately and to recognize the population of the study. Table 2 illustrates the summary of the descriptive statistics characteristics related to the variables used in this study.

Description: In this study, the variable SL is the dependent variable. OV and HL_IN are independent variables and ROE and Size, and ROA and LEV are control variables. SL: Debt cost of bank; OV: Overvaluation; HL_IN: Information asymmetric index; LEV: Financial leverage; ROA: Total Return on Assets; ROE: Return on Equity; Size: Company Size.

\section{Testing the first model of research}

In this study, hybrid data is used to test hypotheses. Limer Test is used in combined data method to choose between panel and pooling methods. In this test, we consider two hypotheses:

- $\mathrm{H}_{0}$ : intercepts are the same

- $\mathrm{H}_{1}$ : intercepts are anisotropy

Based on the results of Table 3 and according to that the probability F-statistic with probability value is zero, the $\mathrm{H}_{0}$ hypothesis is rejected based on intercept and the data panel method is selected. Hausman test is used to select between fixed effects and random effects methods. According to the results of the Hausman test, the probability is more than $5 \%$, therefore, the sample random method should be used in the $\mathrm{c}$ regression model (Table 4).

\begin{tabular}{|l|c|c|c|c|c|c|c|}
\hline $\begin{array}{l}\text { Name of the } \\
\text { statistic }\end{array}$ & SL & OV & HL_IN & LEV & Size & ROA & ROE \\
\hline Average & 0.176 & 0.06 & 0.504 & 0.725 & 13.960 & 0.484 & 2.094 \\
\hline Mean & 0.215 & 0.04 & 0.490 & 0.64 & 13.73 & 0.1 & 0.55 \\
\hline $\begin{array}{l}\text { The maximum } \\
\text { amount }\end{array}$ & 1.11 & 0.41 & 1.00 & 58.99 & 21.040 & 38.03 & 183.140 \\
\hline The lowest amount & 0.001 & 0 & 0.00 & 0.010 & 7.750 & -24.86 & -92.2 \\
\hline Standard deviation & 0.203 & 0.067 & 0.32 & 1.8497 & 1.929 & 2.949 & 15.01 \\
\hline Kurtosis & -0.344 & 2.291 & 23.9 & 28.8 & 0.65 & 7.68 & 7 \\
\hline Skewness & 2.771 & 8.835 & 45.89 & 900.98 & 3.88 & 95.64 & 77.12 \\
\hline number of samples & 43 & 43 & 43 & 43 & 43 & 43 & 43 \\
\hline $\begin{array}{l}\text { Number of } \\
\text { observations }\end{array}$ & 215 & 215 & 215 & 215 & 215 & 215 & 215 \\
\hline
\end{tabular}

SL: Debt cost of bank; OV: Over-valuation; HL_IN: Information Asymmetry Index; LEV: Financial Leverage; ROA: Return on Assets; ROE: Return on Equity.

Table 2: Results of descriptive statistics used in this study for variables.

\begin{tabular}{|c|c|c|c|}
\hline Possibility & Degrees of freedom & Amount of statistics & Description \\
\hline 0.00 & -273.818 & 2.012596 & F statistic \\
\hline \multicolumn{3}{|c|}{ Table 3: Results of the test of F statistics. } \\
\hline
\end{tabular}

\begin{tabular}{|c|c|c|c|}
\hline Possibility & Degrees of freedom & Amount of statistics & Description \\
\hline 0.0837 & 4 & 8.225468 & F-statistic \\
\hline \multicolumn{3}{|c|}{ Table 4: Hausman test results. } \\
\hline
\end{tabular}

As mentioned in previous steps, the first hypothesis of this research is:

There is a significant relationship between the over-valuation and the bank's debt cost of company.

As a result, research hypothesis will be as follows:

- $\mathrm{H}_{0}$ : There is no a signification relationship between the overvaluation and the bank's debt cost of companies.

- $\mathrm{H}_{1}$ : There is a significant relationship between the overvaluation and the bank's debt cost of company.

Description: In this study, the variable SL is the dependent variable. OV and HL_IN are independent variables and ROE and Size, and ROA and LEV are control variables. SL: debt cost of bank, OV: overvaluation, HL_IN: Information asymmetric index, LEV: Financial leverage, ROA: Total Return on Assets, ROE: Return on Equity, SIZE: Company size.

In this study, if the hypothesis $\mathrm{H}_{0}$ is correct, it means that none of the explanatory variables (independent and control) has a significant effect on the changes of the dependent variable (debt cost), and the changes are merely random. According to the results of the main model test in Table 5, it can be seen that the P-value is related to F-statistic, which indicates the significance of the total regression equal to 0.000 and show that the model at the level of confidence $99 \%$ is significant. Meanwhile, according to the independent variable coefficient (overvaluation), it can be stated that there is a positive and significant relationship between this variable and the bank cost. In addition, according to the results, because the Watson Camera test statistic is 2.052. So, it can be accepted the assumption of the lack of correlation between the remainder. The results presented in Table 5 also show that $0.38 \%$ of the changes associated with the dependent variable are explained by independent variables.

\section{Testing the first model of research}

As described in the previous steps, the data panel model is used to test the general specification, at Limer f-statistic should be used to verify the panel's data and then, using the Hausman test, one of two models of fixed or random effects is selected for model estimation. The results of $\mathrm{F}$ Limer test are mentioned in Table 6.

Based on the results of Table 6, and according to that the F-statistic is less than $5 \%$, then the $\mathrm{H}_{0}$ hypothesis that the equality of intercepts is rejected and the data panel method is selected. Also, according to the results of two tests in the $\mathrm{F}$ test and the Hausman test, the probability is less than $5 \%$, so the fixed effects method should be used in the corresponding regression model. The results are shown in Tables 7 and 8 .

Description: in this study, the variable SL is the dependent variable. OV and HL_IN variables are independent variables and ROE and Size, and ROA and LEV are control variables.

According to the results of the main model test in Table 5, it can be seen that the P-value is related to F-statistic, which indicates the significance of the total regression equal to 0.000 and show that the model at the level of confidence $99 \%$ is significant. Meanwhile, according to the independent variable coefficient (over-valuation), it can be stated that there is a positive and significant relationship between this variable and the bank cost. In addition, according to 
Citation: Reza-Zomorodian G, Firozjaee MR (2018) Investigating the Relationship between Over-Valuation Stock Price and Debt Costs of Companies with Financial Health Based on Black, Scholes and Merton (BSM) Model. J Account Mark 7: 275. doi: 10.4172/2168-9601.1000275

Page 4 of 5

\begin{tabular}{|c|c|c|c|c|}
\hline Variable & Coefficient & Std. Error & t-Statistic & 12.097 \\
\hline C & 0.283 & 0.023 & 24.665 \\
\hline OV & 0.474 & 0.019 & 2.572 & 0.000 \\
\hline LEV & 0.070 & 0.027 & -3.121 & 0.000 \\
\hline Size & -0.082 & 0.026 & -2.019 \\
\hline ROA & -1.439 & 0.713 & -4.352 & 0.002 \\
\hline $\begin{array}{c}\text { The coefficient of } \\
\text { determination }\end{array}$ & $\begin{array}{c}\text { Adjusted coefficient of } \\
\text { determination }\end{array}$ & $\begin{array}{c}\text { Deviation from mean } \\
\text { regression }\end{array}$ & F statistics & Probability of F statistics \\
\hline 0.389 & 3.385 & 0.670 & 0.000 \\
\hline
\end{tabular}

Table 5: Test results of the first hypothesis test.

\begin{tabular}{|c|c|c|c|}
\hline Possibility & Degrees of freedom & Amount of statistics & Description \\
\hline 0.0149 & -119.675 & 1.337 & F-statistic \\
\hline
\end{tabular}

Table 6: Test results of F-statistic.

\begin{tabular}{|c|c|c|c|}
\hline Possibility & Degrees of freedom & Amount of statistics & Description \\
\hline 0.000 & 3 & 41.772 & F-statistic \\
\hline \multicolumn{3}{|c}{ Table 7: Hausman test results. }
\end{tabular}

the results, because the Watson Camera test statistic is 2.152 . So, it can be accepted the assumption of the lack of correlation between the remainder. The results presented in Table 6 also show that $0.41 \%$ of the changes associated with the dependent variable are explained by independent variables. The results presented in Table 6 also show that $0.41 \%$ of the changes associated with the dependent variable are explained by independent variables. In addition, due to the fact that the main model also increases the coefficient of determination and changes in the angle coefficient of the overvalued variable, it can be argued that information asymmetry can be considered as an aggravating factor of the relationship between the two over-valued variables and the cost Debt should be considered in companies with financial health of Tehran Stock Exchange.

\section{Conclusion}

In this study, we collect data on 43 healthy companies listed in Tehran Stock Exchange for the period of 5-year from 2011 to 2015. According to the purpose of this study, 215 observations are used in a five-year period. The first hypothesis is considered investigating the relationship between the over-valuation and the debt cost of companies in Iran. Based on the results of two done tests on the first hypothesis regression model ( $\mathrm{F}$ test and Hausman test), the obtained possibility is less than and more than $5 \%$, respectively. Therefore, panel method and random effects have to be used in the corresponding regression model. Meanwhile, the results of the first hypothesis test show that there is a negative and significant relationship between over-valuation and debt costs of companies in the studied period. Based on the reported results, the coefficient of determination is 0.39 , indicating that approximately 0.39 of the changes of the dependent variable can be explained with the variables of the model. Meanwhile, according to the fact that the result of Watson's camera is 2.055 , the results of this test have not autocorrelation problem and are reliable. These results confirm the findings of Chio and Shi on the existence of a positive and significant relationship between over-valuation and debt costs.

In the second hypothesis, we consider to evaluate the effect of information asymmetry on the relationship between over-valuation and the debt cost of bank. According to the results of two tests of $\mathrm{F}$ test and the Hausman test, the obtained probability is less than $5 \%$. Therefore, the fixed effects method should be used in the corresponding regression model. Based on the obtained results from the second

\begin{tabular}{|c|c|c|c|c|c|}
\hline Variable & Coefficient & Std. Error & t-Statistic & \multicolumn{2}{|c|}{ Prob. } \\
\hline C & 0.295 & 0.026 & 11.478 & \multicolumn{2}{|c|}{0.000} \\
\hline OV & 0.537 & 0.017 & 31.192 & \multicolumn{2}{|c|}{0.000} \\
\hline HL_IN & 0.340 & 0.223 & 1.525 & \multicolumn{2}{|c|}{0.021} \\
\hline LEV & 0.130 & 0.029 & 4.445 & \multicolumn{2}{|c|}{0.010} \\
\hline Size & -0.086 & 0.022 & -3.859 & \multicolumn{2}{|c|}{0.002} \\
\hline ROA & -1.445 & 0.763 & -1.894 & \multicolumn{2}{|c|}{0.050} \\
\hline ROE & -1.122 & 0.280 & -4.007 & \multicolumn{2}{|c|}{0.000} \\
\hline $\begin{array}{c}\text { The } \\
\text { coefficient of } \\
\text { determination }\end{array}$ & $\begin{array}{c}\text { Adjusted } \\
\text { coefficient of } \\
\text { determination }\end{array}$ & $\begin{array}{l}\text { Deviation } \\
\text { from mean } \\
\text { regression }\end{array}$ & F-statistic & $\begin{array}{c}\text { Probability } \\
\text { of } \\
\text { F-statistic }\end{array}$ & $\begin{array}{l}\text { Watson } \\
\text { Camera }\end{array}$ \\
\hline 0.410 & 0.401 & 0.710 & 99.420 & 0.000 & 2.152 \\
\hline
\end{tabular}

Table 8: Test results of the second hypothesis.

hypothesis test, the lack of information asymmetry intensifies the relationship between over-valuation and the debt cost of bank. As the findings of Chio and Shi, the results of this study confirm the positive and significant relationship between over-valuation and debt costs.

Based on the reported results, the coefficient of determination is 0.41 , indicating that approximately 0.41 changes of the dependent variable can be explained with the variables of the model. Meanwhile, according to that the result of Watson's camera is 2.15 , the results of this test have not autocorrelation problem and are reliable.

\section{References}

1. Chiou CL, Shu PG (2016) Overvaluation and the Cost of Bank Debt. International Review of Economics and Finance 48: 235-234.

2. Rostamy AAA, Aghaei MA, Biglari $V$ (2008) Empirical investigation of the ability of sensitivity of stock prices to earnings news in predicting earnings management and management forecast errors. Asia-Pacific Financial Markets 15: $209-228$

3. Modigliani F, Miller MH (1958) The cost of capital, corporation finance and the theory of investment. Am Econ Rev 48: 261-297.

4. Houmes RE, Skantz TR (2010) Highly valued equity and discretionary accruals. Journal of Business Finance and Accounting 37: 60-92.

5. Polk C, Sapienza P (2008) The stock market and corporate investment: A test of catering theory. Rev Financial Stud 22: 187-217.

6. Hua ZJ (2001) Financial constraints in the listed companies investment Explanation from the views of structure of equity [J]. J Finance 11: 012.

7. Sham FF, Ahmadvand M, Dezfuli H (2017) Measuring default risk using the Black-Scholes-Merton Model and testing its relationship with corporate governance factors. Scientific magazine of Financial Engineering and Management of Securities 30.

8. Loughran T, Ritter JR (1997 The operating performance of firms conducting seasoned equity offerings. J Finance 52: 1823-1850.

9. McLaughlin R, Safieddine A, Vasudevan GK (1996) The operating performance of seasoned equity issuers: Free cash flow and post-issue performance. Financial Management, pp: 41-53.

10. Bhattacharya N, Desai H, Venkataraman K (2013) Does earnings quality affect 
Citation: Reza-Zomorodian G, Firozjaee MR (2018) Investigating the Relationship between Over-Valuation Stock Price and Debt Costs of Companies with Financial Health Based on Black, Scholes and Merton (BSM) Model. J Account Mark 7: 275. doi: 10.4172/2168-9601.1000275

information asymmetry? Evidence from trading costs. Contemp Account Res 30: $482-516$

11. Wasan S, Boone JP (2010) Do accruals exacerbate information asymmetry in the market? Advances in Accounting 26: 66-78.

12. Spiess DK, Graves JA (1995) Underperformance in long-run stock returns following seasoned equity offerings. J Financial Econ. 23: 139-183.

13. Habib A, Hasan MM (2017) Business strategy, overvalued equities, and stock price crash risk. Research in International Business and Finance 39: 389-405.

14. Izadinia N, Mirzaee M (2015) The effect of over-valuation of stock on the relationship between audit quality and discretionary accruals. Quarterly Journal of Research of Empirical Financial Accounting Studies 12: 73-96.

15. Rezaei SA (2014) The relationship between over-valuation stock and shareholders' wealth by smoothing earnings in listed companies in Tehran Stock Exchange. Accounting and Audit Reviews 54: 137-154.
16. Vadiee $\mathrm{MH}$, Azimifar $\mathrm{F}$ (2012) over-valuation of stock and its relation to discretionary accruals. Journal of Scientific and Research of Accounting Progress in Shiraz 4: 179-203.

17. Babrbaian A (2011) The relationship between over-valuation of stock and earnings management. Daneshvar Raftar 11: 39-45.

18. Mousavi SM, Khalat BH, Waghfi SH (2012) The effect of over-valuation of stock on earnings management. Scientific Magazine of Accounting Knowledge 9: 166.

19. Li D, Xia Y (2015) The effect of stock liquidity on default risk. University of Hong Kong.

20. Rhodes-Kropf M, Robinson DT, Viswanathan S (2002) Valuation waves and merger activity: The empirical evidence. Journal of Financial Economics 77 $561-603$.

21. Lin JB, Pantzalis C, Park JC (2007) Corporate use of derivatives and excess value of diversification. J Bank Finance 31: 889-913. 